\title{
CrimRxiv
}

\section{Survey of State Attorneys General, United States, 2014 (ICPSR 37949)}

United States. Bureau of Justice Statistics

Published on: Jun 29, 2021

DOI: 10.21428/cb6ab371.825d73ce

License: Creative Commons Attribution 4.0 International License(CC-BY 4.0). 
